Am J Psychiatry. 2008 April ; 165(4): 429-442. doi:10.1176/appi.ajp.2008.07111774.

\title{
Neurobiology of Aggression and Violence
}

\author{
Larry J. Siever, M.D. \\ Department of Psychiatry, Mount Sinai School of Medicine, New York; the Department of \\ Psychiatry, James J. Peters Veterans Affairs Medical Center, Bronx, New York; and VISN 3 \\ Mental Illness Research, Education, and Clinical Center, Bronx, New York
}

\section{Abstract}

Acts of violence account for an estimated 1.43 million deaths worldwide annually. While violence can occur in many contexts, individual acts of aggression account for the majority of instances. In some individuals, repetitive acts of aggression are grounded in an underlying neurobiological susceptibility that is just beginning to be understood. The failure of "top-down" control systems in the prefrontal cortex to modulate aggressive acts that are triggered by anger provoking stimuli appears to play an important role. An imbalance between prefrontal regulatory influences and hyper-responsivity of the amygdala and other limbic regions involved in affective evaluation are implicated. Insufficient serotonergic facilitation of "top-down" control, excessive catecholaminergic stimulation, and subcortical imbalances of glutamatergic/gabaminergic systems as well as pathology in neuropeptide systems involved in the regulation of affiliative behavior may contribute to abnormalities in this circuitry. Thus, pharmacological interventions such as mood stabilizers, which dampen limbic irritability, or selective serotonin reuptake inhibitors (SSRIs), which may enhance "top-down" control, as well as psychosocial interventions to develop alternative coping skills and reinforce reflective delays may be therapeutic.

Human aggression and violence are, unfortunately, ubiquitous phenomena with substantial costs to our society. The detrimental effects of aggression and violence are documented daily in the media. Aggression-defined as hostile, injurious, or destructive behavior often caused by frustration — can be collective or individual. The mental health professional is often called upon to evaluate pathological forms of individual aggression in the clinical, forensic, and school setting, yet the causes and treatment of pathological aggression and violence are poorly understood and understudied (1). While the underpinnings of human aggression are clearly multifactorial, including political, socioeconomic, cultural, medical, and psychological factors, it is also clear that some forms of pathological aggression, such as impulsive aggression (which occurs in the context of emotional arousal and provocation), have an underlying neurobiology that we are only beginning to understand. In this overview, after defining aggression, its prevalence, and its phenomenology, we will address the neurobiology of aggression, particularly pathological forms of impulsive aggression, by discussing the circuitry, both cortical and subcortical, as well as the role of neuromodulators in the initiation and suppression of aggression.

Address correspondence and reprint requests to Dr. Siever, Department of Psychiatry (OOMH), 130 West Kingsbridge Rd., Bronx, NY 10468; Larry.Siever@va.gov.

Dr. Siever reports no competing interests. 


\section{Definitions of Aggression}

Aggression may be classified in a number of ways, for example, by the target of aggression (e.g., self-directed or other-directed), mode of aggression (e.g., physical or verbal, direct or indirect), or cause of aggression (e.g., medical). The most widely utilized and perhaps most heuristically valuable classification of aggression is that of premeditated versus impulsive aggression. Premeditated violence represents a planned behavior that is not typically associated with frustration or response to immediate threat. This form of aggression has also been termed predatory, instrumental, or proactive (2-4). Premeditated violence is not invariably accompanied by autonomic arousal and is planned with clear goals in mind. Sometimes this form of aggression is socially sanctioned, as in wartime. In contrast, impulsive aggression is characterized by high levels of autonomic arousal and precipitation by provocation associated with negative emotions such as anger or fear $(2,3)$. It usually represents a response to a perceived stress. Impulsive aggression, also referred to as reactive aggression, affective aggression, or hostile aggression, becomes pathological when aggressive responses are exaggerated in relation to the emotional provocation that occurs. When a threat is dangerous and imminent, this unpremeditated aggression might be considered defensive aggression and thus part of the normal repertoire of human behavior. Therefore, the line between pathological and impulsive aggression and more normal forms of aggression is not hard and fast, and individuals with pathological aggression may experience or rationalize their violence or aggression as being within the boundaries of normal protective or defensive aggression.

\section{Epidemiology and Genetics}

A recent World Health Organization report provided a 1-year worldwide estimate of 1.43 million people dying from either self-inflicted or interpersonal violence (excluding armed conflict), with a much larger number of nonfatal victims of violence (1), most of which being unplanned acts representing impulsive aggression. Acts of episodic or intermittent impulsive aggression are characteristics of intermittent explosive disorder, as determined by integrated research criteria, which has a lifetime population prevalence of $7.3 \%(5,6)$. It has been reported that one-quarter of all men and approximately one-half as many women report acts of physical aggression after age 18 (7).

Twin and family studies suggest that aggression, particularly irritable/impulsive aggression (as differentiated from premeditated aggression), has substantial heritability (44\%-72\%) (8, $9)$, consistent with a meta-analysis of more than 20 twin studies $(10,11)$. Gene-environment interactions play a major role in aggression and antisocial behaviors $(8,12)$. Environmental factors comprise familial factors, including observing or experiencing aggression as a child or adolescent, as well as cultural and socioeconomic factors that are conducive to aggression (13-15). Individuals with a biological risk for aggression may be particularly vulnerable to the effect of psychosocial adversity (16). For example, genes for the serotonin transporter and monoamine oxidase type A (MAO-A) interact with childhood maltreatment and adversity to predispose to violence (17-19). 
Episodic and impulsive verbal and physical aggression can be associated with a variety of psychiatric disorders and are frequently seen in personality disorders, such as borderline and antisocial personality disorders. The consequences of these behaviors can be serious and include spousal abuse and injury, job loss, criminal assault, rape, or murder. Among violent offenders, $47 \%$ of men and $21 \%$ of women have antisocial personality disorder (20).

\section{Phenomenology}

As illustrated in Figure 1, the susceptibility to aggression may manifest differently depending on the broader psychopathological context in which it occurs. For example, in the context of psychopathy, characterized by a lack of empathy and glib/callous behavior toward others, this susceptibility may manifest itself in instrumental aggression with the antisocial and even criminal acts characteristic of antisocial personality disorder. When the susceptibility is associated with coexisting cognitive impairment or disorganization with impairment of reality testing, aggression may be manifest in psychotic or highly deviant behaviors, as in murder, rape, and serial killings. When such a susceptibility to aggression occurs in an individual predisposed to anxiety who is later exposed to trauma, aggressive acts may be observed when triggered by cues that evoke the original trauma, as in the context of posttraumatic stress disorder (PTSD). When coupled with extreme emotional sensitivity and dysregulation, impulsive or reactive aggression often occurs in an interpersonal context, as in borderline personality disorder. A susceptibility to aggression may be enabled by an altered mood or anxiety state, as in bipolar disorder, generalized anxiety disorder, or panic disorder (21). Episodic aggression and violence often accompany dementia. Perhaps the most common comorbidity is a substance abuse disorder, which contributes to both the cognitive distortions and disinhibition associated with substances of abuse, such as alcohol or stimulants.

In any of these contexts, impulsive aggression may be conceived as a lower threshold for activation of motoric aggressive responses to external stimuli without adequate reflection or regard for the aversive consequences of the behavior. This aggressive diathesis can be conceptualized in terms of an imbalance between the "top-down" control or "brakes" provided by the orbital frontal cortex and anterior cingulate cortex, which are involved in calibration of behavior to social cues and predicting expectancies of reward and punishment (2), modulating or suppressing aggressive behavior with negative consequences, and excessive "bottom-up" "drives" triggered or signaled by limbic regions, such as the amygdala and insula. As shown in Figure 2, an emotionally provocative or challenging stimulus that serves as a trigger to the aggressive event will initially be processed by auditory, visual, and other sensory processing centers. At this stage, sensory deficits such as hearing or visual impairment as well as sensory distortions that might be caused by drugs, alcohol, or metabolic disturbances secondary to illness may result in incomplete or distorted sensory impressions, which can increase the likelihood that the stimulus is perceived as threatening or provocative. After sensory processing, the appraisal of the stimulus will occur in early social information processing centers in visual and auditory integration areas and, ultimately, in higher association regions, including those of the prefrontal, temporal, and parietal cortices. These early information processing stages can be influenced by cultural and social factors that might modulate the perception of the provocation, may become 
distorted by cognitive impairment secondary to information processing deficits leading to a propensity to paranoid ideation or referential ideas, and may be biased by negative schema that might be a function of a developmental stress/trauma or enduring negative experiences leading to diminished trust. Ultimately, processing of these stimuli in relation to past emotional conditioning encoded in the amygdala and related limbic regions will trigger the "drive" to an aggressive action, while the orbital frontal cortex and anterior cingular gyrus will provide "top-down" modulation of these emotional responses and behaviors and serve to suppress behaviors with negative consequences.

An imbalance between limbic "drives" and prefrontal control mechanisms may be important for a range of psychiatric pathology provoked by negative stimulation, including not only aggressive disorders characterized by externally directed behaviors but also withdrawal behaviors associated with anxiety disorders, such as PTSD and mood disorders. More specific genetic and physiological susceptibilities, in conjunction with an experiential history of aggression, may serve to condition the responses to emotional provocation in the direction of aggression. For example, functional magnetic resonance imaging (fMRI) studies suggest that patients with borderline personality disorder, who often experience anger and aggression dyscontrol, are particularly sensitive to faces with angry expressions $(22,23)$, while a sensitivity to fear inducing stimuli or facial expressions may be particularly salient in anxiety disorders. As shown in Figure 3, a variety of more specific abnormalities in brain structural circuitry and neuromodulators that regulate these systems may play convergent roles in contributing to the susceptibility to aggression. This article elaborates on these domains and cites relevant studies. Most of the studies reviewed were performed in specific populations prone to impulsive aggression, including patients with antisocial or borderline personality disorders and intermittent explosive disorder, as determined by integrated research criteria (24), as well as in criminal offenders.

\section{Brain Circuitry}

\section{Cortex}

The critical role of the prefrontal control in aggressive and dyssocial behaviors, consistent with the frontal cortex modulating subcortical behavior, was first recognized in the context of prefrontal cortical lesions resulting in disinhibited aggressive behavior. These lesions may occur as a result of trauma, tumors, or even metabolic disturbances that affect the prefrontal cortex. A prime example of this disinhibition is found in the often cited case of Phineas Gage, a dependable, stable railroad worker who was injured by a tamping rod that penetrated his skull through his orbital frontal cortex (the anterior and mesial aspects and anterior cingulate) (25). He became angry, irritable, and showed poor social judgment following the injury. Childhood and adult-onset damage to the ventromedial prefrontal cortex results in severe disruption of emotion, which leads to diminished real-world competence (26). Patients with frontal lobe injuries, including the orbital frontal cortex, are more likely to use physical intimidation and threats in conflict situations (27).

The temporal lobe is also implicated in the susceptibility to violence and aggression. Most commonly, this relationship is manifest in the aggressive behaviors of patients with tumors of the temporal lobe but can also be associated with other temporal lesions (28). The 
temporal lobe is often the site of localized seizure activity, and temporal lobe epilepsy may be associated with subacute postictal aggressive behaviors (29).

Structural imaging-While lesion studies evaluate effects of damage to specific brain regions, structural imaging paradigms measure naturalistic variability in volumes and shapes of brain structures. Reductions in prefrontal gray matter that are presumably based in aberrant development have been reported in individuals with antisocial personality disorder and are often associated with autonomic deficits $(30,31)$. Significant volume reductions have been demonstrated in the left orbital frontal cortex and right anterior cingulate cortex in patients with borderline personality disorder (32), most marked in Brodmann's area 24, which has also been implicated in functional imaging studies of these patients. The temporal cortex, particularly the medial temporal cortex and hippocampus, has also been demonstrated to have structural alterations, including altered asymmetry in antisocial subjects (33).

Orbital frontal/cingulate cortical processing efficiency-Functional brain imagining permits an assessment of brain activation patterns in specific regions of interest in individuals with a history of recurrent episodic violent behavior. Initial studies focusing on psychiatric patients with a history of violence demonstrated decreased glucose metabolism using a positron emission tomography with $\left[{ }^{18}\right]$ fluorodeoxyglucose (FDG-PET) paradigm in the temporal and frontal cortices (34). Similar results were obtained in a study of murderers (35). An inverse relationship has also been reported between the history of impulsive aggressive behavior and glucose metabolism in the orbital frontal cortex and right temporal cortex, with reductions of metabolism in prefrontal Brodmann's areas 46 and 6 in patients with borderline personality disorder (36). In a PET study evaluating responses to the probe metachlorophenylpiperazine, decrements in the lateral, medial, and orbital frontal cortices were found at baseline in men with a history of physical aggression and in the orbital frontal cortex for both men and women with a history of physical aggression (37). In an imaging study of an unrestrained aggressive scenario, healthy volunteers demonstrated blood flow reductions in the orbital frontal cortex, suggesting a release of "top-down" control of aggression (38). While participating in a laboratory designed to provoke aggression, the Point Subtraction Aggression Paradigm, patients with intermittent explosive disorder, as determined by integrated research criteria, and borderline personality disorder made more aggressive responses relative to comparison subjects (39). In the Point Subtraction Aggression Paradigm, patients with borderline personality disorder who were characterized by anger dyscontrol showed diminished responses to provocation in the medial frontal cortex and the anterior frontal cortex relative to comparison subjects but greater responses in the orbital frontal cortex, presumably to dampen aggressive responses (39). In an fMRI paradigm (40), when viewing negative pictures compared with rest, patients with borderline personality disorder showed greater activity relative to healthy comparison subjects in the amygdala, fusiform gyrus, paraphippocampul gyrus, cerebellar declive, ventrolateral prefrontal cortex, occipital visual areas, and regions related to sensory, emotional, and facial processing, while healthy comparison subjects showed greater activity in the insula, involved in visceral emotional processing, and the dorsomedial/dorsolateral prefrontal cortex, involved in cognitive processing. When attempting to suppress negative emotions, 
borderline personality disorder patients showed less activation of the anterior cingulate, pregenual anterior cingulate, and in-traparietal sulci relative to comparison subjects (41). These anomalous patterns of activation suggest inefficient processing by cortical regions in the service of suppressing behaviors with negative consequences triggered by these provocative stimuli.

\section{Limbic System/Subcortical Structures}

Structural/functional imaging - The other critical abnormality implicated in impulsive aggression and violence is hyperactivity of the limbic system, including structures such as the amygdala, in response to negative or provocative stimuli, particularly anger provoking stimuli. Activation in these systems in the face of diminished "top-down" regulation can lead to disinhibited anger and aggression. Enhanced responses of the amygdala have been reported in patients with borderline personality disorder toward negatively valenced pictures (42), faces with neutral, positive, and negative emotions (43), and traumatic scenes (44) relative to healthy comparison subjects. In more recent studies from our laboratory, increased activation of the amygdala was demonstrated in borderline personality disorder patients toward negative pictures versus a resting state $(40,45)$. Hyper-reactive responses to the amygdala have also been reported in relation to traumatic scripts in borderline personality disorder patients (46). Some studies have suggested reduced amygdala volumes in borderline personality disorder subjects relative to comparison subjects (cf. 46), while others have not (37).

Emotional responsivity mediated by limbic regions can also be measured with a nonverbal psychophysiological paradigm measuring affective startle. Research shows that while viewing unpleasant stimuli compared with neutral stimuli, people exhibit greater amplitude of the startle eye-blink response during the presentation of a brief static noise burst (47). In a recent study from our program, we found that patients with borderline personality disorder exhibited exaggerated startle potentiation relative to healthy comparison subjects while viewing negative words (e.g., suicidal, alone), which is particularly salient for people with borderline personality disorder (48). The two groups (borderline personality and healthy comparison) did not differ on startle amplitude during the presentation of neutral words (e.g., collect, regular). The findings also showed that among the borderline personality disorder patients, greater symptom severity was associated with greater affective startle during presentation of unpleasant words. Consistent with symptoms of affective dysregulation, these results suggest that borderline personality disorder patients exhibit hyper-responsivity to unpleasant stimuli. In a more recent study utilizing fMRI during this affective startle task, patients with borderline personality disorder showed greater amygdala activation and greater startle response when the startle was introduced during unpleasant words rather than during neutral or pleasant words (unpublished data of Hazlett et al., 2007). In contrast, the instrumental aggression characteristic of psychopathy and antisocial personality disorder is associated with reduced amygdala responsiveness, autonomic activity, and aversive conditioning $(2,49)$.

Hypothalamic activation has also been associated with aggression in domestic violence perpetrators (50), consistent with anterior hypothalamic regulation of aggression $(2,51)$. 
Abnormalities in hippocampal function have also been reported in antisocial and violent subjects $(33,52)$, consistent with hippocampus modulating aggression $(33,53)$.

Kindling-The phenomenon of "kindling" occurs when circuits subjected to repeated stimulation become sensitized to future stimulation (54). While generally considered in the contexts of repeated episodes of bipolar illness, "kindling" can also apply to repeated explosive or violent outbursts (e.g., outbursts associated with drug use) (55) that are responsive to the beneficial effects of anticonvulsants (56). The regions that are implicated in the "kindling" phenomenon include regions of the limbic cortex, such as the amygdala and enterorhinal cortex, which may be implicated in impulsive aggression.

\section{Neuromodulators}

\section{Neurotransmitters}

Serotonin-Serotonin facilitates prefrontal cortical regions, such as the orbital frontal cortex and anterior cingulate cortex, that are involved in modulating and often suppressing the emergence of aggressive behaviors primarily by acting on serotonin $5-\mathrm{HT}_{2}$ receptors in these regions. Thus, deficiencies in serotonergic innervation of these regions could be expected to result in disinhibited aggression upon provocation. This model is supported by studies that have shown that selective serotonin reuptake inhibitors (SSRIs) reduce impulsive aggression (57) as well as neurobiological studies that have implicated reduced concentrations of the serotonergic metabolite 5-hydroxy-indoleacetic acid (5-HIAA) and reduced neuroendocrine responses to serotonergic probes (58-60) in aggressive personality disorder patients or individuals who have had violent suicide attempts $(61,62)$. Animal models in rhesus and macaque monkeys support an association between lower serotonergic activity and aggression in freely moving primates (63). Interestingly, serotonin depletion is also implicated in decreased learning of cooperation and diminished perception of trustworthiness (64).

Antagonists of 5- $\mathrm{HT}_{2 \mathrm{~A}}$ receptors reduce impulsivity in animal models (65), and atypical neuroleptics with prominent 5- $\mathrm{HT}_{2 \mathrm{~A}}$ antagonism have antiaggressive efficacy in clinical populations (66). Agonists, on the other hand, reduce impulsivity at the $5-\mathrm{HT}_{2 \mathrm{C}}$ receptor (65), suggesting that the two receptor subtypes may have complementary roles in the regulation of aggression consistent with their reciprocal modulation in animal model systems (67).

Pharmacological probe studies assess net serotonergic activity by measuring responses of hormones, such as prolactin, to serotonergic releasing agents, including d, l-fenfluramine. Blunted prolactin responses are associated with suicide attempts in depressed and personality disorder patients and impulsive aggression in personality disorder patients, more specifically, borderline personality disorder and those criteria of borderline personality disorder reflecting impulsive aggression (68). Metachlorophe-nylpiperazine, which directly activates the $5-\mathrm{HT}_{2 \mathrm{C}}$ receptor, has been associated with blunted prolactin responses and increased impulsivity and hyperactivity $(65-67,69)$. Ipsapirone and buspirone, which are agonists for the $5-\mathrm{HT}_{1 \mathrm{~A}}$ receptor, also produce reduced neuroendocrine responses (11). In paradigms assessing receptors on peripheral blood elements, increased 5- $\mathrm{HT}_{2 \mathrm{~A}}$ receptor 
binding in platelets has been associated with experimentally induced depletions in serotonergic activity (e.g., in tryptophan depletion paradigms). Such increases are also correlated with impulsive aggression in subjects with personality disorders, suggesting increased aggression in the face of reduced serotonergic activity (70).

More recently, imaging studies have pointed to reduced orbital and ventral medial prefrontal activation in response to $\mathrm{d}$, l-fenfluramine in impulsive aggressive personality disorder patients (61), in borderline personality disorder patients (who are often characterized by impulsive aggression) (71), and in depressed patients with a history of suicide attempts (72). Personality disorder patients with intermittent explosive disorder, as determined by integrated research criteria, characterized by periodic episodes of dyscontrol of aggression and violence, demonstrated diminished activity in the orbital frontal cortex and adjacent ventral medial cortex relative to comparison subjects but did not necessarily differ in other regions of interest, including the parietal cortex (61). Statistical parameter mapping suggested that this difference was highly localized to a small region of the orbital frontal cortex near the site of the lesion of Phineas Gage. A study of borderline personality disorder patients showed reduced activation to fenfluramine in similar regions (71). The glucose metabolic response to the selective $5-\mathrm{HT}_{2 \mathrm{C}}$ agonist metachlo-rophenylpiperazine was also reduced in patients with intermittent explosive disorder, as determined by integrated research criteria, particularly in the left hemisphere and anterior cingulate, as opposed to the posterior cingulate (37). Comparison subjects demonstrated an expected positive correlation between the amygdala and prefrontal cortex activity at rest, while this correlation was zero order to negative in borderline personality disorder patients with intermittent explosive disorder, as determined by integrated research criteria (37).

PET imaging studies have illuminated the activity-specific components of the serotonergic system, including the serotonin transporter and $5-\mathrm{HT}_{2 \mathrm{~A}}$ receptor. Serotonin transporter activity as labeled by $\left[{ }^{11} \mathrm{C}\right](\mathrm{McNeil} 5652)$ was reduced in number in the cingulate cortex in patients with aggressive personality disorder relative to comparison subjects (73), and interim results using a more cortically sensitive probe, $\left[{ }^{11} \mathrm{C}\right] \mathrm{DASB}$, suggest significant reductions in transporter binding in both the anterior cingulate cortex and orbital frontal cortex in aggressive patients (unpublished data of Siever et al., 2007). Receptor binding of $5-\mathrm{HT}_{2 \mathrm{~A}}$, which can be measured by $\left[{ }^{11} \mathrm{C}\right] \mathrm{MDL} 100907$ or altanserin, is significantly increased in physically aggressive patients with personality disorders (74) and in female borderline personality disorder patients (75), consistent with postmortem (76) and platelet studies (77) suggesting increased $5-\mathrm{HT}_{2 \mathrm{~A}}$ receptor binding associated with suicide. These studies are consistent with $5 \mathrm{HT}_{2 \mathrm{~A}}$ antagonism reducing impulsivity (65), but such antagonists have yet to be studied in relation to impulsive aggression in clinical populations. Pilot data suggest reductions in $5-\mathrm{HT}_{2 \mathrm{~A}}$ binding with treatment with the SSRI fluoxetine, which may parallel reductions in aggression symptoms (unpublished data of Siever et al., 2007), implicating increased $5 \mathrm{HT}_{2 \mathrm{~A}}$ receptor sensitivity associated with aggression and its reduction with efficacious treatment.

Catecholamines-The catecholamines dopamine and norepinephrine may enhance the likelihood of other directed aggression. Thus, depressed patients with blunted noradrenergic responsiveness do not show the externally directed aggression found in personality disorder 
patients, in whom blunted serotonergic activity is associated with normal to increased noradrenergic activity $(60,78)$. The growth hormone response to the alpha adrenergic receptor agonist clonidine has been correlated with irritability, although not with aggression per se, suggesting that increased noradrenergic receptor sensitivity may be related to hyperreactivity to the environment, which indirectly enhances the likelihood of aggression (79). Dopamine is involved in the initiation and performance of aggressive behavior (80), and decreased $\mathrm{D}_{1}$ receptors have been implicated in depressed patients with anger attacks (81).

Acetylcholine-Abnormalities in cholinergic activity may contribute to hyperactivity of subcortical limbic regions and dysphoria or irritability, which can trigger aggression. The acetylcholinesterase inhibitor physostigmine, which has been demonstrated to increase depressive affect in patients with major mood disorder, also induced increases in depression scores in borderline personality disorder patients compared with placebo but not in healthy comparison subjects, and these increases were correlated with the trait of affective instability in a personality disorder cohort (82).

Glutamatergic/gabaminergic systems-Imbalance in glutamatergic/gabaminergic activity may contribute to hyperactivity of subcortical limbic regions. Gamma-aminobutyric acid type $\mathrm{A}(\mathrm{GABA}[\mathrm{A}])$ receptor modulators may enhance aggression (83), and tiagabine, a GABA uptake inhibitor, decreases aggression, possibly by suppressing reactions to aversive stimuli (84). Thus, reduced activity at GABA receptors may contribute to aggression, while glutamatergic enhancement increases aggression (85), raising the possibility of an imbalance in the GABA/ glutamatergic systems in aggression (86).

\section{Neuropeptides}

Vasopressin-Vasopressin is implicated in both affiliative behaviors and aggression. A positive correlation has been reported between CSF vasopressin concentrations and life history of aggression in personality disorder patients (87), even when controlling for serotonergic activity, paralleling animal studies in which higher densities of anterior hypothalamic neurons containing vasopressin were associated with greater selective aggression toward unfamiliar conspecifics (51). Vasopressin $1 \mathrm{~b}$ receptor knock-out mice conversely show decreases in this type of aggression (88). Interestingly, increases in serotonergic activity can reduce concentrations of vasopressin centrally (89).

Oxytocin-Oxytocin is implicated in affiliative behavior and trust (90-92). It also reduces amygdala activity in humans (93), and thus deficits in oxytocin might contribute to the hostility, fear, and mistrust that may provide the preconditions for the emergence of aggression. In fact, oxytocin knock-out mice display exaggerated aggressive behavior (94). Oxytocin concentrations in CSF are inversely correlated with aggression (unpublished data of Coccaro et al., 2006).

Opiates-Opiates have been related to aggression, particularly self-directed aggression. Increased metenkephalin has been associated with self-injurious behavior (95), while opiate antagonists have generally diminished self-injurious acts (96). Reduced CSF endogenous opioid concentrations have been associated with self-injurious behaviors in patients with 
borderline personality disorder (97), consistent with the clinical observation of the propensity of borderline personality disorder patients to seek relief with opiate pain medications. Reduced opioids may be associated with increased separation/abandonment distress and rejection sensitivity that may heighten the likelihood of aggressive behavior (98, 99). Reduced presynaptic opiate activity may upregulate postsynaptic $\mu$-opioid receptors, and thus dramatic relief of pain may result when opiates are released in the context of selfinjurious behavior.

Neurosteroids-While numerous reports have suggested correlations between plasma testosterone concentration and aggression, these relationships have not always been replicated and have been extensively reviewed elsewhere (100). High concentrations of testosterone have been reported in populations characterized by high aggression, including criminals with personality disorders, alcoholic violent offenders, and spousal abusers (101), although these concentrations were not found in a recent study of CSF testosterone in patients with intermittent explosive disorder, as determined by integrated research criteria (101). Testosterone and steroids may induce aggression and enhance responsiveness of brain circuitry related to social aggression (102).

Hypothalamopituitary adrenal axis—Cortisol concentrations have generally been found to be low in individuals with high aggression, including populations of volunteers, adolescents with disruptive behavior, antisocial criminal offenders, and alcoholic perpetrators of domestic violence (11), and aggressive behavior has been linked to corticotropin releasing factor reactive autoantibodies (103).

Sterols and fatty acids-A number of retrospective studies of individuals who have attempted suicide suggest that reduced cholesterol is associated with aggressive behavior, including violent crimes (104) and violent suicide attempts (105), paralleling relationships between low cholesterol and aggression in monkeys (106). A reduction of cholesterol by drug treatment might increase the likelihood of suicide or trauma related to aggression, an effect possibly mediated by serotonin (107), but this has not been established definitively.

\section{Neurocognitive-Neuropsychological Impairment}

Aggressive behavior has often been associated with poor executive function and verbal processing in adolescents and adults (108). Cognitive performance is particularly impaired in neuropsychological tests that are sensitive to frontal and temporal dysfunction (109). Tasks that rely on behavioral inhibition were most likely to show deficits in individuals with aggressive behavior and violence, and reduced responses in evoked potential tasks have predicted impulsiveness in aggressive prison populations (11).

\section{Laboratory/Behavioral Tasks-Intermediate Phenotypes}

A number of laboratory tests that measure more specific components of impulsive aggression have been utilized to parse the more global concept of impulsive aggression, and thus the specific mechanisms of aggression could be investigated more specifically. These tests can serve as intermediate phenotypes or endophenotypes that may be more closely 
associated with genetic substrates than the more inclusive clinical construct. For example, the Point Subtraction Aggression Paradigm is a laboratory test for aggression that can elicit aggressive responses in individuals susceptible to aggression and therefore assay the predisposition to aggression that may not always manifest itself in the individual's naturalistic environment-for example, where such an individual isolates themselves or avoids provocation. Thus, the Point Subtraction Aggression Paradigm provides a more objective, less context-sensitive, and more mechanistically specific measure of aggression. It relies on an assessment of aggressive responses in a computerized game in which subjects believe that they are playing in a fictitious network of individuals. When subjects find that points are being taken from them by someone they presume to be another player (generated by computer), those predisposed to aggression may "retaliate" by taking points from the perceived other subject. The number of aggressive responses correlates with aggressive behavior and has been validated in violent parolees (110). The "go/no go" version of the Continuous Performance Task measures the capacity to inhibit responses that may also be relevant to the impulsivity aspect of aggression (111). The Immediate Memory Task is a measure of impulsivity that has been extensively validated (112). These laboratory tests as well as self-report measures, including the Buss-Perry Aggression Questionnaire, Barratt Impulsivity Scale, and Life History of Aggression scales (113), can be used in both neurobiological and genetic studies. Many of these measures are found to be heritable in twin studies (unpublished data of Jacobson et al., 2006; [8]) and to distinguish patients characterized by aggression, such as borderline personality disorder patients, from comparison groups (unpublished data of Siever et al., 2006).

\section{Genotypes}

A number of candidate genes have been explored in relation to impulsive aggression or disorders characterized by high aggression. These include serotonin-related genes, catecholamine-related genes, and other neuromodulator-related genes. For example, the 5$\mathrm{HT}_{2 \mathrm{~A}}$ TYR 452 allele has been associated with childhood-onset aggression (114). An allele for low MAO-A activity has been reported to be associated with aggression in a Dutch pedigree (115). Subjects with low activity of the MAO-A gene display more aggression and exhibit significant volume reductions in the bilateral amygdala, anterior cingulate cortex, and subgenual anterior cingulate cortex (116). An allele of MAO-A has also been associated with borderline personality disorder (117). MAO-A activity interacts with rearing to influence aggressive behavior in rhesus monkeys (118) and humans (17-19). Serotonin transporter (5-HTT) polymorphisms are also associated with aggression in some populations $(119,120)$. Differences in allele frequency of a single nucleotide polymorphism, rs165599, in the catecholamine-O-methyltransferase gene (121) have been associated with increased physical aggression and aggressive responses on the Point Subtraction Aggression Paradigm in patients with personality disorders (122). The tryptophan hydroxylase- $1\left(\mathrm{TPH}_{1}\right)$ allele has been associated with aggression in some $(123,124)$ but not all $(125)$ studies. Alleles in the $\mathrm{TPH}_{2}$ gene, which controls serotonin synthesis in the brain $(126,127)$, have been associated with aggression and borderline personality disorder in personality disorder patients (unpublished data of Siever et al., 2007; unpublished data of Kennedy et al., 2007) and are related to emotional instability in healthy volunteers (128). A number of other genes in the 
serotonergic and catecholaminergic systems have been associated with impulse control deficits (129). For example, DRD2 and DRD4 gene variants interact to predict adolescent conduct disorder and adolescent antisocial behavior $(130,131)$.

These allelic variances may interact with the environment so that, for example, individuals with low MAO-A activity when exposed to childhood maltreatment are more likely to exhibit antisocial behavior as adults, while severe childhood maltreatment has a more modest effect on individuals with high MAO-A activity (18).

\section{Model of Neurobiology of Aggression}

Aggression emerges when the "drive" of limbic-mediated affective prefrontal response to anger producing or provocative stimuli is insufficiently constrained by inhibition and is channeled into violent behavior. Excessive reactivity in the amygdala, coupled with inadequate prefrontal regulation, serves to increase the likelihood of aggressive behavior. Developmental alterations in prefrontal-subcortical circuitry as well as neuromodulator abnormality appear to play a role. Serotonin facilitates prefrontal inhibition, and thus insufficient serotonergic activity can enhance aggression. Gabaminergic activity at GABA(A) receptors can reduce subcortical reactivity, and therefore reduced gabaminergic activity can increase aggression. Reductions in oxytocin activity and increases in vasopressin activity also may serve to induce aggression.

These findings may reflect aberrant development patterns. For example, developmentally based reductions in serotonergic innervation of the prefrontal cortex reflected in reduced transporter binding in the cingulate (76) may result in less serotonergic facilitation of prefrontal cortex regulation. Agonism of 5- $\mathrm{HT}_{2 \mathrm{~A}}$ may increase impulsivity, while $5-\mathrm{HT}_{2 \mathrm{C}}$ agonism may decrease it (65), and thus an imbalance between these receptors with increased serotonergic activity at the 5- $\mathrm{HT}_{2 \mathrm{~A}}$ receptor-consistent with $5-\mathrm{HT}_{2 \mathrm{~A}}$ binding assessment in platelet, brain imaging, and postmortem studies-and decreased 5- $\mathrm{HT}_{2 \mathrm{C}}$ receptor sensitivity —consistent with reduced responses to metachlorophenylpiperazine and fenfluramine-may enhance the likelihood of impulsive aggression. Trophic factors operating during development may contribute to this pattern, and reduced cFos responses to fenfluramine, increased 5- $\mathrm{HT}_{2 \mathrm{~A}}$, and reduced 5- $\mathrm{HT}_{2 \mathrm{C}}$ binding have been identified in a brain-derived neurotrophic factor knockdown mouse characterized by aggressive behavior (132). Genetic variation in serotonergic genes such as $\mathrm{TPH}_{2}$ (133) or 5-HTT (18) may also contribute to altered serotonergic development. Fluoxetine may reverse this pattern by increasing presynaptic availability, decreasing $5-\mathrm{HT}_{2 \mathrm{~A}}$ binding and enhancing signal at $5-\mathrm{HT}_{2 \mathrm{C}}$ receptors (Figure 4, Figure 5). While mechanisms of aggression may vary between psychiatric disorders (Figure 6), they tend to involve an imbalance of cortical/subcortical regulation.

\section{Implications for Treatment}

This review is not intended to assess the clinical evidence for or against specific interventions, but rather it overviews the neurobiological mechanisms that might be considered in treatment strategies, both with existing drugs and those drugs that have yet to be developed. Deficits in prefrontal inhibition providing insufficient "brakes" on impulsive 
aggressive behavior may be enhanced by SSRIs, which can facilitate inhibition of subcortical regions by increasing serotonin availability in prefrontal regions, particularly the orbital cortex (134) (Figure 7), while mood stabilizers and anticonvulsants, which alter glutamatergic/gabaminergic balance, reduce irritability and impulsivity (135). Opiate antagonists can reduce self-injurious behavior (97). Psychotherapies, either psychodynamic, such as transference-based therapy, or behavioral, such as dialectical behavioral therapy, may serve to increase the capacity to delay and inhibit aggressive behaviors, increasing verbal/reflective function capacities as well as helping to reduce excess sensitivity to emotions.

\section{Future Directions}

As highlighted in a recent commentary in the Journal (136), there is a paucity of research pertaining to the underlying causes of violence and aggression given the extensive morbidity associated with these behaviors. A number of more specific issues need to be further addressed. First, the circuitry implicated in the regulation of aggression is closely related to the circuitry involved in fear conditioning and affective control. A more elaborated delineation of the commonalities and differences between the regions and circuits involved in these different paradigms, which have many overlapping and synergistic clinical features, needs to be better defined. Second, the precise ways in which the neuromodulators cited interact with and modulate the brain circuitry associated with aggression need more clarification. For example, it is clear that serotonin modulates prefrontal activity, specifically the orbital frontal and anterior cingulate cortices, while the neuropeptides modulate limbic/ subcortical structures, but greater regional specificity is required to better understand the role of these neuromodulators. Third, the interrelationship between the systems of neuromodulators needs further clarification. For example, serotonin has a reciprocal interaction with catecholamines but also has relationships with peptides such as vasopressin and oxytocin. A more detailed understanding of these relationships in relation to aggression is required. Fourth, the biological measures that reflect these neurocircuits and neuromodulator activity need to be gauged prior to and following effective treatments to determine which variables might predict successful treatment responses and which variables might change with treatment. Last, novel pharmacological interventions, including 5-HT2A antagonists, 5-HT2C agonists, opiate-mixed agonist/antagonists, and oxytocin, need to be evaluated clinically.

Recommended strategies include the use of neuromodulators as treatment or probes with specific laboratory behavioral tasks that monitor aggression, affiliation, trust, and emotion regulation. Imaging studies that capture circuitry involved in the expression of aggression, the perception of threat, and the perception of emotion, for example, will be useful in further dissecting the circuitry and assessing effects of treatment. Thus, advances in the understanding of the neurobiology of violence can contribute meaningfully to a rational assessment and treatment of individuals with pathological aggression and a predisposition to violence. 


\section{Acknowledgments}

Supported by the following grants: NIMH MH-56140 and NIMH MH-63875 (Dr. Siever); Veterans Affairs Merit Review Grant (7609-028) (Dr. Siever); and by the Veterans Affairs VISN 3 Mental Illness Research, Education and Clinical Center. This article was made possible by grant number MO1-RR-00071, from the National Center for Research Resources (NCRR), a component of NIH.

The contents of this article are solely the responsibility of the author and do not necessarily represent the official views of NCRR or NIH.

\section{References}

1. World Health Organization. Third Milestones of a Global Campaign for Violence Prevention Report 2007: Scaling Up. Geneva: Switzerland, WHO; 2007.

2. Blair RJ. The roles of orbital frontal cortex in the modulation of antisocial behavior. Brain Cogn. 2004; 55:198-208. [PubMed: 15134853]

3. Meloy JR. Empirical basis and forensic application of affective and predatory violence. Aust N Z J Psychiatry. 2006; 40:539-547. [PubMed: 16756578]

4. Barratt ES, Felthous AR. Impulsive versus premeditated aggression: implications for mens rea decisions. Behav Sci Law. 2003; 21:619-630. [PubMed: 14502692]

5. Coccaro EF, Schmidt CA, Samuels JF, Nestadt G. Lifetime and 1-month prevalence rates of intermittent explosive disorder in a community sample. J Clin Psychiatry. 2004; 65:820-824. [PubMed: 15291659]

6. Kessler RC, Coccaro EF, Murizio F, Jaeger S, Jin R, Walters E. The prevalence and correlates of DSM-IV intermittent explosive disorder in the National Comorbidity Survey Replication. Arch Gen Psychiatry. 2006; 63:669-678. [PubMed: 16754840]

7. Robins, LN.; Regier, DA. Psychiatric Disorders in America. New York: Free Press; 1991.

8. Seroczynski AD, Bergeman CS, Coccaro EF. Etiology of the impulsivity/aggression relationship: genes or environment? Psychiatry Res. 1999; 86:41-57. [PubMed: 10359481]

9. Coccaro EF, Bergeman CS, Kavoussi RJ, Seroczynski AD. Heritability of aggression and irritability: a twin study of the Buss-Durkee aggression scales in adult male subjects. Biol Psychiatry. 1997; 41:273-284. [PubMed: 9024950]

10. Miles DR, Carey G. Genetic and environmental architecture of human aggression. J Pers Soc Psychol. 1997; 72:207-217. [PubMed: 9008382]

11. Coccaro, EF.; Siever, LJ. The neuropsychopharmacology of personality disorders, in Psychopharmacology: The Fourth Generation of Progress. Bloom, FE.; Kupfer, DJ., editors. New York: Raven Press; 1995. p. 1567-1579.

12. Moffitt TE. The new look of behavioral genetics in developmental psychopathology: geneenvironment interplay in antisocial behaviors. Psychol Bull. 2005; 131:533-554. [PubMed: 16060801]

13. Deater-Deckard K, Dodge KA, Bates JE, Pettit GS. Multiple risk factors in the development of externalizing behavior problems: group and individual differences. Dev Psychopathol. 1998; 10:469-493. [PubMed: 9741678]

14. Fergusson DM, Lynskey MT. Physical punishment/maltreatment during childhood and adjustment in young adulthood. Child Abuse Negl. 1997; 21:617-630. [PubMed: 9238545]

15. Fergusson DM, Horwood J, Lynskey MT. Childhood sexual abuse and psychiatric disorder in young adulthood, II: psychiatric outcomes of childhood sexual abuse. J Am Child Adolesc Psychiatry. 1996; 34:1365-1374.

16. Marks DJ, Miller SR, Schulz KP, Newcorn JH, Halperin JM. The interaction of psychosocial adversity and biological risk in childhood aggression. Psychiatry Res. 2007; 151:221-230. [PubMed: 17408754]

17. Reif A, Rosler M, Freitag CM, Schneider M, Eujen A, Kissling C, Wenzler D, Jacob CP, RetzJunginger P, Thome J, Lesch KP, Retz W. Nature and nurture predispose to violent behavior: serotonergic genes and adverse childhood environment. Neuropsychopharmacology. 2007; 32:2375-2383. [PubMed: 17342170] 
18. Caspi A, McClay J, Moffitt TE, Mill J, Martin J, Craig IW, Taylor A, Poulton R. Role of genotype in the cycle of violence in maltreated children. Science. 2002; 297:851-854. [PubMed: 12161658]

19. Kim-Cohen J, Caspi A, Taylor A, Williams B, Newcombe R, Craig IW, Moffitt TE. MAOA, maltreatment, and gene-environment interaction predicting children's mental health: new evidence and a meta-analysis. Mol Psychiatry. 2006; 11:903-913. [PubMed: 16801953]

20. Fazel S, Danesh J. Serious mental disorder in 23,000 prisoners: a systematic review of 62 surveys. Lancet. 2002; 359:545-550. [PubMed: 11867106]

21. Swann AC. Neuroreceptor mechanisms of aggression and its treatment. J Clin Psychiatry. 2003; 64(suppl 4):26-35. [PubMed: 12672262]

22. Best M, Williams JM, Coccaro EF. Evidence for a dysfunctional prefrontal circuit in patients with an impulsive aggressive disorder. Proc Natl Acad Sci U S A. 2002; 99:8448-8453. [PubMed: 12034876]

23. Coccaro EF, McCloskey MS, Fitzgerald DA, Phan KL. Amygdala and orbitofrontal reactivity to social threat in individuals with impulsive aggression. Biol Psychiatry. 2007; 62:168-178. [PubMed: 17210136]

24. Coccaro EF. Intermittent explosive disorder. Curr Psychiatry Rep. 2000; 2:67-71. [PubMed: 11122935]

25. Damasio H, Grabowski T, Frank R, Galaburda AM, Damasio AR. The return of Phineas Gage: clues about the grain from the skull of a famous patient. Science. 1994; 264:1102-1105. [PubMed: 8178168]

26. Anderson SW, Barrash J, Bechara A, Tranel D. Impairments of emotion and real-world complex behavior following childhood- or adult-onset damage to ventromedial prefrontal cortex. J Int Neuropsychol Soc. 2006; 12:224-235. [PubMed: 16573856]

27. Grafman J, Schwab K, Warden D, Pridgen A, Brown HR, Salazar AM. Frontal lobe injuries, violence and aggression: a report of the Vietnam Head Injury Study. Neurology. 1996; 46:12311238. [PubMed: 8628458]

28. Tonkonogy JM, Geller JL. Hypothalamic lesions and intermittent explosive disorder. J Neuropsychiatry Clin Neurosci. 1992; 4:45-50. [PubMed: 1627961]

29. Ito M, Okazaki M, Takahashi S, Muramatsu R, Kato M, Onuma T. Subacute postictal aggression in patients with epilepsy. Epilepsy Behav. 2007; 10:611-614. [PubMed: 17418643]

30. Raine A, Lencz T, Bihrle S, LaCasse L, Colletti P. Reduced prefrontal gray volume and autonomic deficits in antisocial personality disorder. Arch Gen Psychiatry. 2000; 57:119-127. [PubMed: 10665614]

31. Narayan VM, Narr KL, Kumari V, Woods RP, Thompson PM, Toga AW, Sharma T. Regional cortical thinning in subjects with violent antisocial personality disorder or schizophrenia. Am J Psychiatry. 2007; 164:1418-1427. [PubMed: 17728428]

32. Hazlett EA, New AS, Newmark R, Haznedar MM, Lo JN, Speiser LJ, Chen AD, Mitropoulou V, Minzenberg M, Siever LJ, Buchsbaum MS. Reduced anterior and posterior cingulated gray matter in borderline personality disorder. Biol Psychiatry. 2005; 58:614-623. [PubMed: 15993861]

33. Raine A, Ishikawa SS, Arce E, Lencz T, Knuth HK, Bihrle S, LaCasse L, Colletti P. Hippocampal structural asymmetry in unsuccessful psychopaths. Biol Psychiatry. 2004; 55:185-191. [PubMed: 14732599]

34. Volkow ND, Tancredi LR, Grant C, Gillespie H, Valentine A, Mullani N, Wang GJ, Hollister L. Brain glucose metabolism in violent psychiatric patients: a preliminary study. Psychiatry Res. 1995; 61:243-253. [PubMed: 8748468]

35. Raine A, Meloy JR, Bihrle S, Stoddard J, LaCasse L, Buchsbaum MS. Reduced prefrontal and increased subcortical brain functioning assess using positron emission tomography in predatory and affective murderers. Behav Sci Law. 1998; 16:319-332. [PubMed: 9768464]

36. Goyer PF, Andreason PJH, Semple WE, Clayton AH, King AC, Compton-Toth BA, Schulz SC, Cohen RM. Positron-emission tomography and personality disorders. Neuropsychopharmacology. 1994; 10:21-28. [PubMed: 8179791]

37. New AS, Hazlett EA, Buchsbaum MS, Goodman M, Mitelman SA, Newmark R, Trisdorfer R, Hanedar MM, Koenigsberg HW, Flory J, Siever LJ. Amygdala-prefrontal disconnection in 
borderline personality disorder. Neuropsychopharmacology. 2007; 32:1629-1640. [PubMed: 17203018]

38. Pietrini P, Guazzelli M, Basso G, Jaffe K, Grafman J. Neural correlates of imaginal aggressive behavior assessed by positron emission tomography in healthy subjects. Am J Psychiatry. 2000; 157:1772-1781. [PubMed: 11058474]

39. New AS, Hazlett EA, Goodman M, Koenigsberg HW, Newmark R, Trisdorfer R, Buchsbaum MS, Siever LJ. Laboratory induced aggression: a PET study of borderline personality disorder (abstract). Soc Biol Psychiatry. 2006; 59:47s.

40. Koenigsberg HW, Prohovnik I, Lee H, Pizzarello S, New AS, Siever LJ. Neural correlates of the processing of negative and positive social scenes in borderline personality disorder (abstract). Biol Psychiatry. 2007; 61:104s.

41. Koenigsberg HW, Fan J, Ochsner K, Pizzarello S, New AS, Siever LJ. Neural correlates of efforts to downregulate emotion in borderline personality disorder (abstract). Biol Psychiatry. 2007; 61:200.

42. Herpetz SC, Dietrich TM, Wenning B, Krings T, Eberich SG, Willmes K, Thorn A, Sass H. Evidence of abnormal amygdala functioning in borderline personality disorder: a functional MRI study. Biol Psychiatry. 2001; 50:292-298. [PubMed: 11522264]

43. Donegan NH, Sanislow CA, Blumberg HP, Fulbright RK, Lacadie C, Skudlarski P, Gore JC, Olson IR, McGlashan TH, Wexler BE. Amygdala hyper-reactivity in borderline personality disorder: implications for emotional dysregulation. Biol Psychiatry. 2003; 54:1284-1293. [PubMed: 14643096]

44. Schmahl CG, Elzinga BM, Ebner UW, Simms T, Sanislow C, Vermetten E, McClashan TH, Bremner JD. Psychophysiological reactivity to traumatic and abandonment scripts in borderline personality and posttraumatic stress disorders: a preliminary report. Psychiatry Res. 2004; 126:3342. [PubMed: 15081625]

45. Minzenberg MJ, Fan J, New AS, Tang CY, Siever LJ. Front-limbic dysfunction in response to facial emotion in borderline personality disorder: an event-related fMRI study. Psychiatry Res. 2007; 155:231-243. [PubMed: 17601709]

46. Schmahl CG, Vermetten E, Elzinga BM, Bremner JD. Magnetic resonance imaging of hippocampal and amygdala volume in women with childhood abuse and borderline personality disorder. Psychiatric Res. 2003; 122:193-198.

47. Lang PJ, Bradley MM, Cuthbert BN. Emotion, attention and the startle reflex. Psychol Rev. 1990; 97:377-395. [PubMed: 2200076]

48. Hazlett EA, Spieser LJ, Goodman M, Roy M, Carrizal M, Wynn JK, Williams WC, Romero M, Minzenberg MJ, Siever LJ, New AS. Exaggerated affect-modulated startle during unpleasant stimuli in borderline personality disorder. Biol Psychiatry. 2007; 62:250-255. [PubMed: 17258691]

49. Kiehl KA, Smith AM, Hare RD, Mendrek A, Forster BB, Bring J, Liddle PF. Limbic abnormalities in affective processing by criminal psychopaths as revealed by functional magnetic resonance imaging. Biol Psychiatry. 2001; 50:677-684. [PubMed: 11704074]

50. George DT, Rawlings RR, Williams WA, Phillips MJ, Fong G, Kerich M, Momenan R, Umhau JC, Hommer D. A select group of perpetrators of domestic violence: evidence of decreased metabolism in the right hypothalamus and reduced relationships between cortical/subcortical brain structures in positron emission tomography. Psychiatry Res. 2004; 130:11-25. [PubMed: 14972365]

51. Gobrogge KL, Liu Y, Jia X, Wang Z. Anterior hypothalamic neural activation and neurochemical associations with aggression in pair-bonded male prairie voles. J Comp Neurol. 2007; 502:1109_ 1122. [PubMed: 17444499]

52. Critchley HD, Simmons A, Daly EM, Russell A, van Amelsvoort T, Robertson DM, Glover A, Murphy DG. Prefrontal and medial temporal correlates of repetitive violence to self and others. Biol Psychiatry. 2000; 47:928-934. [PubMed: 10807966]

53. Gregg TR, Siegel A. Brain structures and neurotransmitters regulating aggression in cats: implications for human aggression. Prog Neuropsychopharmacol Biol Psychiatry. 2001; 25:91140. [PubMed: 11263761] 
54. Post RM. Kindling and sensitization as models for affective episode recurrence, cyclicity, and tolerance phenomena. Neurosci Biobehav Rev. 2007; 31:858-873. [PubMed: 17555817]

55. Davis WM. Psychopharmacologic violence associated with cocaine abuse: kindling of a limbic dyscontrol syndrome? Prog Neuropsychopharmacol Biol Psychiatry. 1996; 20:1273-1300. [PubMed: 9004337]

56. Hollander EA, Swann AC, Coccaro EF, Jiang P, Smith TB. Impact of trait impulsivity and state aggression on divalproex versus placebo response in borderline personality disorder. Am J Psychiatry. 2005; 162:621-624. [PubMed: 15741486]

57. Coccaro EF, Kavoussi RJ. Fluoxetine and impulsive aggressive behavior in personality-disordered subjects. Arch Gen Psychiatry. 1997; 54:1081-1088. [PubMed: 9400343]

58. Asberg M, Traksman L, Thoren P. 5-HIAA in the cerebrospinal fluid: a biochemical suicide predictor? Arch Gen Psychiatry. 1976; 33:1193-1197. [PubMed: 971028]

59. Coccaro EF, Kavoussi RJ, Cooper TB, Hauger RL. Central serotonin activity and aggression: inverse relationship with prolactin response to d-fenfluramine, but not CSF 5-HIAA concentration, in human subjects. Am J Psychiatry. 1997; 154:1430-1435. [PubMed: 9326827]

60. Siever L, Trestman RL. The serotonin system and aggressive personality disorder. Int Clin Psychopharmacology. 1993; 8(suppl 2):33-39.

61. Siever LJ, Buchsbaum MS, New AS, Spiegel-Cohen J, Wei T, Hazlett EA, Sevin E, Nunn M, Mitropoulou V. d,l-fenfluramine response in impulsive personality disorder assessed with $\left[{ }^{18}\right.$ F]fluorodeoxyglucose positron emission tomography. Neuropsychopharmacology. 1999; 20:413-423. [PubMed: 10192822]

62. New AS, Trestman RL, Mitropoulou V, Benishay DS, Coccaro E, Silverman J, Siever LJ. Serotonergic function and self-injurious behavior in personality disorder patients. Psychiatry Res. 1997; 69:17-26. [PubMed: 9080541]

63. Higley JD, Mehlman PT, Taub DM, Higley SB, Suomi SJ, Vickers JH, Linnoila M. Cerebrospinal fluid monoamine and adrenal correlates of aggression in free-ranging rhesus monkeys. Arch Gen Psychiatry. 1992; 49:436-441. [PubMed: 1376105]

64. Wood RM, Rilling JK, Sanfey AG, Bhagwagar Z, Rogers RD. Effects of tryptophan depletion on the performance of an iterated prisoner's dilemma game in healthy adults. Neuropsychopharmacology. 2006; 31:1075-1084. [PubMed: 16407905]

65. Winstanley CA. 5- $\mathrm{HT}_{2 \mathrm{~A}}$ and $5-\mathrm{HT}_{2 \mathrm{C}}$ receptor antagonists have opposing effects on a measure of impulsivity: interactions with global 5-HT depletion. Psychopharmacology (Berl). 2004; 176:376385. [PubMed: 15232674]

66. Krakowski MI, Czobor P, Citrome L, Bark N, Cooper TB. Atypical antipsychotic agents in the treatment of violent patients with schizophrenia and schizoaffective disorder. Arch Gen Psychiatry. 2006; 63:622-629. [PubMed: 16754835]

67. Bubar MJ, Cunningham KA. Serotonin $5-\mathrm{HT}_{2 \mathrm{~A}}$ and $5-\mathrm{HT}_{2 \mathrm{C}}$ receptors as potential targets for modulation of psychostimulant use and dependence. Curr Top Med Chem. 2006; 6:1971-1985. [PubMed: 17017968]

68. Cocarro EF, Siever LJ, Klar HM, Mauerer G, Cochrane K, Cooper TB, Mohs RC, Davis KL. Serotonergic studies in patients with affective and personality disorder: correlates with suicidal and impulsive aggressive behavior. Arch Gen Psychiatry. 1989; 46:587-599. [PubMed: 2735812]

69. Coccaro EF, Kavoussi RJ, Trestman RL, Gabriel SM, Cooper TB, Siever LJ. Hormonal responses to meta-chlorophenylpiperazine (m-CPP) are undiminished by acute m-CPP pretreatment. Psychiatry Res. 1996; 62:139-145. [PubMed: 8771611]

70. Coccaro EF, Kavoussi RJ, Sheline YI, Berman ME, Cseranansky JG. Impulsive aggression in personality disorder correlates with platelet $5-\mathrm{HT}_{2 \mathrm{~A}}$ receptor binding. Neuropsychopharmacology. 1997; 16:211-216. [PubMed: 9138437]

71. Soloff PH, Meltzer CC, Greer PJ, Constantine D, Kelly TM. A fenfluramine-activated FDG-PET study of borderline personality disorder. Biol Psychiatry. 2000; 47:540-547. [PubMed: 10715360]

72. Mann JJ, McBride PA, Brown RP, Linnoila M, Leon AC, DeMeo M, Mieczkowski T, Myers JE, Stanley M. Relationships between central and peripheral serotonin indexes in depressed and suicidal psychiatric inpatients. Arch Gen Psychiatry. 1992; 49:442-446. [PubMed: 1376106] 
73. Frankle WG, Lombardo I, New AS, Goodman M, Talbot PS, Huang Y, Hwang DR, Slifstein M, Curry S, Abi-Dargham A, Laruelle M, Siever LJ. Brain serotonin transporter distribution in subjects with impulsive aggressivity: a positron emission study with $\left[{ }^{11} \mathrm{C}\right] \mathrm{McN} 5652$. Am J Psychiatry. 2005; 162:915-923. [PubMed: 15863793]

74. Siever L, Frankle WG, Goldman D, Gelernter J, Hu X, Abi-Dargham A, Laruelle M. The serotonin transporter binding and genotypes in impulsive personality disorders (abstract). Biol Psychiatry. 2006; 59:100s.

75. Soloff PH, Price JC, Meltzer CC, Fabio A, Frank GK, Kaye WH. 5-HT 2 A receptor binding is increased in borderline personality disorder. Biol Psychiatry. 2007; 62:580-587. [PubMed: 17448449]

76. Arango V, Ernsberger P, Marzuk PM, Chen JS, Tierney H, Stanley M, Reis DJ, Mann JJ. Autoradiographic demonstration of increased serotonin 5- $\mathrm{HT}_{2}$ and beta-adrenergic receptor binding sites in the brain of suicide victims. Arch Gen Psychiatry. 1990; 47:1038-1047. [PubMed: 2173513]

77. Pandey GN, Pandey SC, Dwivedi Y, Sharma RP, Janicak PG, Davis JM. Platelet serotonin-2 A receptors: a potential biological marker for suicidal behavior. Am J Psychiatry. 1995; 152:850_ 855. [PubMed: 7755113]

78. Siever LJ, Trestman RL, Coccaro EF, Bernstein DP, Gabriel SM, Owen K, Maran M, Lawrence T, Rosenthal J, Horvath TB. The growth hormone response to clonidine in acute and remitted depressed male patients. Neuropsychopharmacology. 1992; 6:165-177. [PubMed: 1599607]

79. Coccaro EF, Lawrence T, Trestman R, Gabriel S, Klar HM, Siever LJ. Growth hormone responses to intravenous clonidine challenge correlate with behavioral irritability in psychiatric patients and health volunteers. Psychiatry Res. 1991; 39:129-139. [PubMed: 1665918]

80. De Almeida RM, Ferrari PF, Parmigiani S, Miczek KA. Escalated aggressive behavior: dopamine, serotonin and GABA. Eur J Pharmacol. 2005; 526:51-64. [PubMed: 16325649]

81. Dougherty DD, Bonab AA, Ottowitz WE, Livni E, Alpert NM, Rauch SL, Fava M, Fischman AJ. Decreased striatal $\mathrm{D}_{1}$ binding as measured using PET and $\left[{ }^{11} \mathrm{C}\right] \mathrm{SCH} 23,390$ in patients with major depression with anger attacks. Depress Anxiety. 2006; 23:175-177. [PubMed: 16528700]

82. Steinberg BJ, Trestman R, Mitropoulou V, Serby M, Silverman J, Coccaro EF, Weston S, deVegvar M, Siever LJ. Depressive response to physostigmine challenge in borderline personality disorder patients. Neuropsychopharmacology. 1997; 17:264-273. [PubMed: 9326751]

83. Fish EW, DeBold JF, Miczek KA. Aggressive behavior as a reinforcer in mice: activation by allopregnanolone. Psychopharmacology (Berl). 2002; 163:459-466. [PubMed: 12373446]

84. Lieving LM, Cherek DR, Lane SD, Tcheremissine OV, Nouvion S. Effects of acute tiagabine administration on aggressive responses of adult male parolees. J Psychopharmacol. 2007 [Epub ahead of print].

85. Lumley LA, Robinson CL, Slusher BS, Wozniak K, Dawood M, Meyerhoff JL. Reduced isolationinduced aggressiveness in mice following NAALADase inhibition. Psychopharmacology (Berl). 2004; 171:375-381. [PubMed: 14634711]

86. Hrabovszky E, Halasz J, Meelis W, Kruk MR, Liposits Z, Haller J. Neurochemical characterization of hypothalamic neurons involved in attack behavior: glutamatergic dominance and coexpression of thyrotropin releasing hormone in a subset of glutamatergic neurons. Neuroscience. 2005; 133:657-666. [PubMed: 15908131]

87. Coccaro EF, Kavoussi RJ, Hauger RL, Cooper TB, Ferris CF. Cerebrospinal fluid vasopressin levels: correlates with aggression and serotonin function in personality-disordered subjects. Arch Gen Psychiatry. 1998; 55:708-714. [PubMed: 9707381]

88. Wersinger SR, Caldwell HK, Christiansen M, Young WS3rd. Disruption of the vasopressin 1b receptor gene impairs the attack component of aggressive behavior in mice. Genes Brain Behav. 2007; 6:653-660. [PubMed: 17284170]

89. Ferris CF, Delville Y. Vasopressin and serotonin interactions in the control of agonistic behavior. Psychoneuroendocrinology. 1994; 19:593-601. [PubMed: 7938357]

90. Winslow JT, Insel TR. The social deficits of the oxytocin knockout mouse. Neuropeptides. 2000; 36:221-229. [PubMed: 12359512] 
91. Kosfeld M, Heinrichs M, Zak PJ, Fischbacher U, Fehr E. Oxytocin increases trust in humans. Nature. 2005; 435:673-676. [PubMed: 15931222]

92. Zak PJ, Stanton AA, Ahmadi S. Oxytocin increases generosity in humans. PLoS ONE. 2007; 2:e1128. [PubMed: 17987115]

93. Kirsch P, Esslinger C, Chen Q, Mier D, Lis S, Siddhanti S, Gruppe H, Mattay VS, Gallhofer B, Meyer-Lindenberg A. Oxytocin modulates neural circuitry for social cognition and fear in humans. J Neurosci. 2005; 25:11489-11493. [PubMed: 16339042]

94. Ragnauth AK, Devidze N, Moy V, Finley K, Goodwillie A, Kow LM, Magulia LJ, Pfaff DW. Female oxytocin gene-knockout mice, in semi-natural environment, display exaggerated aggressive behavior. Genes Brain Behav. 2005; 4:229-239. [PubMed: 15924555]

95. Coid J, Allolio B, Rees LH. Raised plasma metenkephalin in patients who habitually mutilate themselves. Lancet. 1983; 2:545-546. [PubMed: 6136696]

96. Symons FJ, Thompson A, Rodriguez MC. Self-injurious behavior and the efficacy of naltrexone treatment: a quantitative synthesis. Ment Retard Dev Disabli Res Rev. 2004; 10:13-22.

97. Sher, L.; Stanley, B. The neurobiology of non-suicidal self injury, in Understanding Non-Suicidal Self-Injury: Current Science and Practice. Nock, MK., editor. Washington, DC: American Psychological Association; in press.

98. Macdonald G, Leary MR. Why does social exclusion hurt?: The relationship between social and physical pain. Psychol Bull. 2005; 131:202-223. [PubMed: 15740417]

99. Panksepp J. Feeling the pain of social loss. Science. 2003; 302:237-239. [PubMed: 14551424]

100. Archer J. The influence of testosterone on human aggression. Br J Psychol. 1991; 82(pt 1):1-28. [PubMed: 2029601]

101. Coccaro EF, Beresford B, Minar P, Kaskow J, Geracioti T. CSF testosterone: relationship to aggression, impulsivity, and venture-someness in adult males with personality disorder. $\mathrm{J}$ Psychiatr Res. 2007; 41:488-492. [PubMed: 16765987]

102. Hermans EJ, Ramsey NF, Honk JV. Exogenous testosterone enhances responsiveness to social threat in neural circuitry of social aggression in humans. Biol Psychiatry. 27 [Epub ahead of print].

103. Fetissov SO, Hallman J, Nilsson I, Lefvert AK, Oreland L, Hokfelt T. Aggressive behavior linked to corticotrophin-reactive autoantibodies. Biol Psychiatry. 2006; 60:799-802. [PubMed: 16876133]

104. Chakrabarti N, Sinha VK. A study of serum lipid profile and serum apolipoproteins A-1 and B in Indian male violent criminal offenders. Crim Behav Ment Health. 2006; 16:177-182. [PubMed: 16838385]

105. Vevera J, Zukov I, Morcinek T, Papezova H. Cholesterol concentrations in violent and nonviolent women suicide attempters. Eur Psychiatry. 2003; 18:23-27. [PubMed: 12648892]

106. Kaplan JR, Shively CA, Fontenot MB, Morgan TM, Howell SM, Manuck SB, Muldoon MF, Mann JJ. Demonstration of an association among dietary cholesterol, central serotonergic activity, and social behavior in monkeys. Psychosom Med. 1994; 56:479-484. [PubMed: 7532867]

107. Golomb BA, Criqui MH, White H, Dimsdale JE. Conceptual foundations of the UCSD Statin Study: a randomized controlled trial assessing the impact of statins on cognition, behavior, and biochemistry. Arch Intern Med. 2004; 164:153-162. [PubMed: 14744838]

108. Dery M, Toupin J, Pauze R, Mercier H, Fortin L. Neuropsychological characteristics of adolescents with conduct disorder: association with attention-deficit-hyperactivity and aggression. J Abnorm Child Psychol. 1999; 27:225-236. [PubMed: 10438188]

109. Yeudall LT, Fromm-Auch D, Davies P. Neuropsychological impairment of persistent delinquency. J Nerv Ment Dis. 1982; 170:257-265. [PubMed: 7069411]

110. Cherek DR, Moeller G, Dougherty DM, Rhoades H. Studies of violent and non-violent male parolees, I: Laboratory and psychometric measurements of aggression. Biol Psychiatry. 1997; 41:514-522. [PubMed: 9046983]

111. LeMarquand DG, Pihl RO, Young SN, Tremblay RE, Seguin JR, Palmour RM, Benkelfat C. Tryptophan depletion, executive functions and disinhibition in aggressive, adolescent males. Neuropsychopharmacology. 1998; 19:333-341. [PubMed: 9718596] 
112. Dougherty DM, Marsh DM, Mathias CW. Immediate and delayed memory tasks: a computerized behavioral measure of memory, attention, and impulsivity. Behav Res Methods Instrum Comput. 2002; 34:391-398. [PubMed: 12395555]

113. Flory JD, Harvey PD, Mitropoulou V, New AS, Silverman JM, Siever LJ, Manuck SB. Dispositional impulsivity in normal and abnormal samples. J Psychiatr Res. 2006; 40:438-447. [PubMed: 16516236]

114. Mik HM, Ehtesham S, Baldassarra L, De Luca V, Davidge K, Bender D, Tharmalingam S, Kenndy JL, Beitchman JH. Serotonin system genes and childhood-onset aggression. Psychiatr Genet. 2007; 17:11. [PubMed: 17167338]

115. Brunner HG, Nelen M, Breakefield XO, Ropers HH, van Oost BA. Abnormal behavior associated with a point mutation in the structural gene for monoamine oxidase A. Science. 1993; 262:578580. [PubMed: 8211186]

116. Meyer-Lindenberg A, Buckholtz JW, Kolachana B, R Hariri A, Pezawas L, Blasi G, Wabnitz A, Honea R, Verchinski B, Callicott JH, Egan M, Mattay V, Weinberger DR. Neural mechanisms of genetic risk for impulsivity and violence in humans. Proc Natl Acad Sci USA. 2006; 103:62696274. [PubMed: 16569698]

117. Ni X, Sicard T, Bulgin N, Bismil R, Chan K, McMain S, Kennedy JL. Monoamine oxidase A gene is associated with borderline personality disorder. Psychiatr Genet. 2007; 17:153-157. [PubMed: 17417058]

118. Newman TK, Syagailo YV, Barr CS, Wendland JR, Champoux M, Graessle M, Suomi SJ, Higley JD, Lesch KP. Monoamine oxidase A gene promoter variation and rearing experience influences aggressive behavior in rhesus monkeys. Biol Psychiatry. 2005; 57:167-172. [PubMed: 15652876]

119. Davridge KM, Atkinson L, Douglas L, Lee V, Shapiro S, Kennedy JL, Beitchman JH. Association of the serotonin transporter and $5-\mathrm{HT}_{1 \text { Dbeta }}$ receptor genes with extreme, persistent and pervasive aggressive behaviour in children. Psychiatr Genet. 2004; 14:143-146. [PubMed: 15318027]

120. Patkar AA, Berrettini WH, Hoehe M, Thronton CC, Gottheil E, Hill K, Weinstein SP. Serotonin transporter polymorphisms and measures of impulsivity, aggression, and sensation seeking among African American cocaine-dependent individuals. Psychiatry Res. 2002; 110:103-115. [PubMed: 12057823]

121. Schifman S, Bronstein M, Sternfeld M, Pistante-Shalom A, Lev-Lehman E, Weizman A, Reznik I, Spivak B, Grisaru N, Karp L, Schiffer R, Kolter M, Strous RD, Swartz-Vanetik M, Knobler HY, Shinar E, Beckmann JS, Yakir B, Risch N, Zak NB, Darvasi A. A highly significant association between a COMT haplotype and schizophrenia. Am J Hum Genetics. 2002; 71:12961302. [PubMed: 12402217]

122. Flory JD, Xu K, New AS, Finch T, Goldman D, Siever LJ. Irritable assault and variation in the COMT gene. Psychiatr Genet. 2007; 17:344-346. [PubMed: 18075475]

123. Nielsen DA, Goldman D, Virkkunen M, Tokola R, Rawlings R, Linnoila M. Suicidality and 5hydroxyindoleacetic acid concentration associated with a tryptophan hydroxylase polymorphism. Arch Gen Psychiatry. 1994; 51:34-38. [PubMed: 7506517]

124. New AS, Gelernter J, Yovell Y, Trestman RL, Nielsen DA, Silverman J, Mitropoulou V, Siever LJ. Tryptophan hydroxylase genotype is associated with impulsive aggression measures. Am J Med Genetics. 1998; 81:13-17. [PubMed: 9514581]

125. Gelernter J, Kranzler H, Lacobelle J. Population studies of polymorphisms at loci of neuropsychiatric interest (tryptophan hydroxylase [TPH], dopamine transporter protein [SLC6A3], $\mathrm{D}_{3}$ dopamine receptor [DRD3], apolipoprotein E [APOE], mu opioid receptor [OPRM1], and ciliary neurotrophic factor [CNTF]). Genomics. 1998; 52:289-297. [PubMed: 9790747]

126. Zhang X, Beaulieu JM, Sotnikova TD, Gainetdinov RR, Caron MG. Tryptophan hydroxylase-2 controls brain serotonin synthesis. Science. 2004; 305:217. [PubMed: 15247473]

127. Zhou Z, Roy A, Lipsky R, Kuchipudi K, Zhu G, Taubman J, Enoch MA, Virkkunen M, Goldman D. Haplotype-based linkage of tryptophan hydroxylase 2 to suicide attempt, major depression, and cerebrospinal fluid 5-hydroxyindoleacetic acid in 4 populations. Arch Gen Psychiatry. 2005; 62:1109-1118. [PubMed: 16203956] 
128. Gutknecht L, Strobel A, Kriegebaum C, Muller J, Zeng Y, Markert C, Escher A, Wendland J, Reif A, Mossner R, Gross C, Broche B, Lesch KP. Tryptophan hydroxylase-2 gene variation influences personality traits and disorders related to emotional dysregulation. Int $\mathrm{J}$ Neuropsychopharmacol. 2007; 10:309-320. [PubMed: 17176492]

129. Kreek MJ, Nielsen DA, Butelman ER, LaForge KS. Genetic influences on impulsivity, risk taking, stress responsivity and vulnerability to drug abuse and addiction. Nat Neurosci. 2005; 8:1450-1457. [PubMed: 16251987]

130. Beaver K, Wright JP, DeLisi M, Walsh A, Vaughn MG, Boisvery D, Vaske J. A gene x gene interaction between DRD2 and DRD4 is associated with conduct disorder and antisocial behavior in males. Behav Brain Funct. 2007; 3:30. [PubMed: 17587443]

131. Congdon Lesch P, Canli T. Analysis of DRD4 and DAT polymorphisms and behavioral inhibition in healthy adults. Am J Med Genet B Neuropsychiatr Genet. 2008; 147:27-32.

132. Lyons WE, Mamounas LA, Ricaurte GA, Coppola V, Reid SW, Bora SH, Wihler C, Koliatsos VE, Tessarollo L. Brain-derived neurotrophic factor-deficient mice develop aggressiveness and hyperphagia in conjunction with brain serotonergic abnormalities. Proc Natl Acad Sci USA. 1999; 96:15239-15244. [PubMed: 10611369]

133. Scheuch K, Lautenschlager M, Grohmann M, Stahlberg S, Kirchheiner J, Zill P, Heinz A, Walther DJ, Priller J. Characterization of a functional promoter polymorphism of the human tryptophan hydroxylase 2 gene in serotonergic raphe neurons. Biol Psychiatry. 2007; 62:12881294. [PubMed: 17568567]

134. New AS, Buchsbaum MS, Hazlett EA, Goodman M, Koenigsberg H, Lo J, Iskander E, Newmark R, Brand J, O'Flynn K, Siever L. Fluoxetine increases relative metabolic rate in prefrontal cortex in impulsive aggression. Psychopharmacology (Berl). 2004; 176:451-458. [PubMed: 15160265]

135. Hollander E, Tracy KA, Swann AC, Coccaro EF, McElroy SL, Wozniak P, Sommerville KW, Nemeroff CB. Divalproex in the treatment of impulsive aggression: efficacy in cluster B personality disorder. Neuropsychopharmacology. 2003; 28:1186-1197. [PubMed: 12700713]

136. Freedman R, Ross R, Michels R, Appelbaum P, Siever L, Binder R, Carpenter W, Friedman SH, Resnick P, Rosenbaum J. Psychiatrists, mental illness, and violence (commentary). Am J Psychiatry. 2007; 164:1315-1317. [PubMed: 17728413] 


\section{Aggression}

(instrumental) in

antisocial personality

disorder

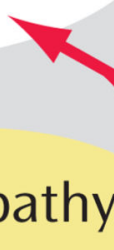

Cognitive impairments/ disorganization
Aggression in psychosis, deviant behaviors
Aggression

(reactive) in borderline personality disorder

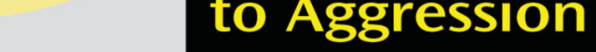

Susceptibility to Aggression

Emotional sensitivity/ dysregulation

FIGURE 1.

Susceptibility to Aggression and Psychiatric Diagnosis 


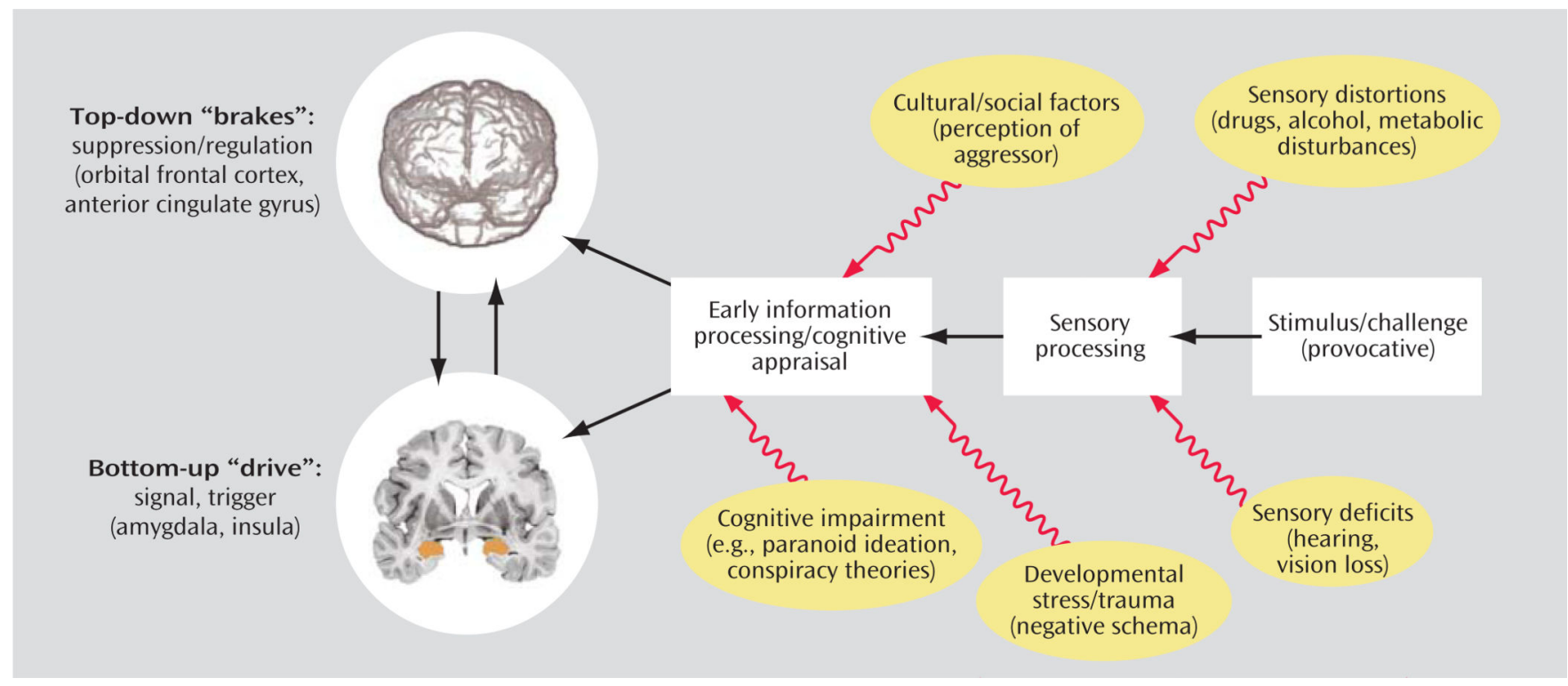

FIGURE 2.

Initiation and Modulation of Aggression ${ }^{\mathrm{a}}$

${ }^{a}$ Figure adapted/modified with permission from S.J. DeArmond et al., "Structure of the Human Brain: A Photographic Atlas, Third Edition" [Oxford University Press, New York, 1989]. Copyright (C) Oxford University Press. A modified version of this figure appeared in Davidson et al., Science 2000; 289:591. 


\section{Brain Circuitry}

Neuromodulators

\section{Cortical}

- Cortical lesion (trauma, tumor)

- Decreased cortical volume (developmental)

- Orbitofrontal/cingulate cortex processing inefficiency

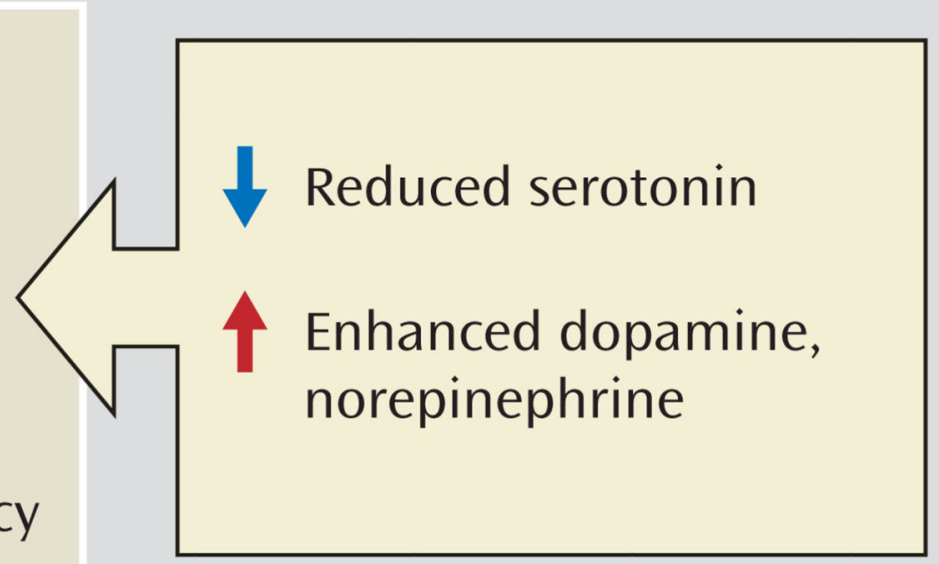

\section{Limbic}

- Hyperactivity (of amygdala, limbic system)

- ? Reduced amygdalar volume

- Emotional hypersensitivity

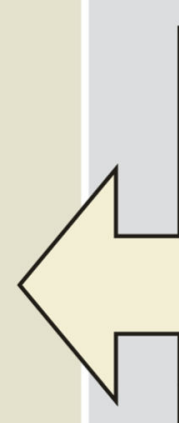

- Kindling $\downarrow$ Reduced GABA

1 Enhanced glutamate

- Enhanced acetylcholine

FIGURE 3.

Brain Circuitry and Neuromodulators Regulating Aggression

Brain Circuitry 


\section{Pretreatment}

\section{Orbital frontal cortex}

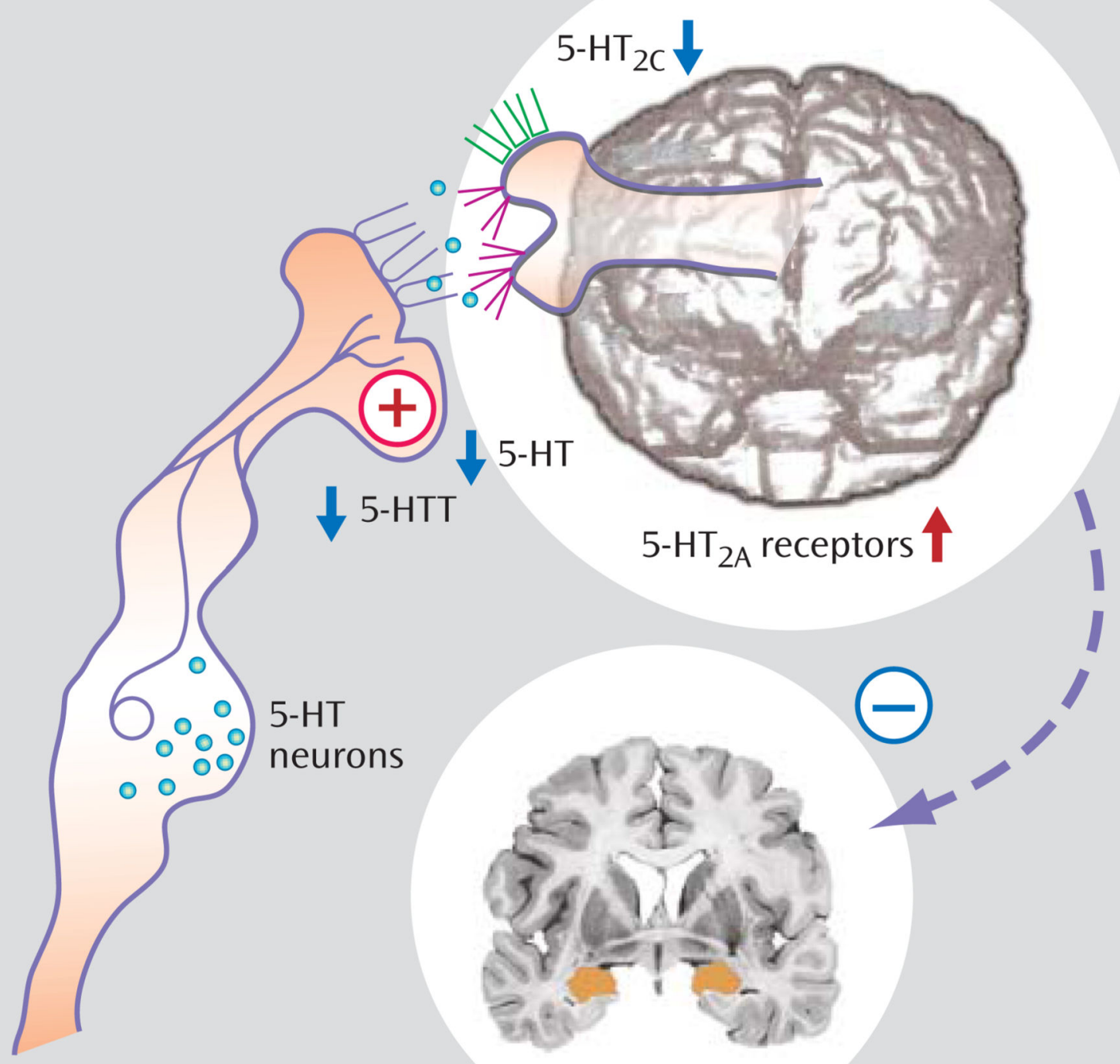

Amygdala

FIGURE 4.

Pretreatment Abnormalities in the Pathophysiology of Aggression ${ }^{\mathrm{a}}$

${ }^{a}$ Figure adapted/modified with permission from S.J. DeArmond et al., "Structure of the Human Brain: A Photographic Atlas, Third Edition" [Oxford University Press, New York, 1989]. Copyright (C) Oxford University Press. A modified version of this figure appeared in Davidson et al., Science 2000; 289:591. 


\section{Posttreatment}

\section{Orbital frontal cortex}

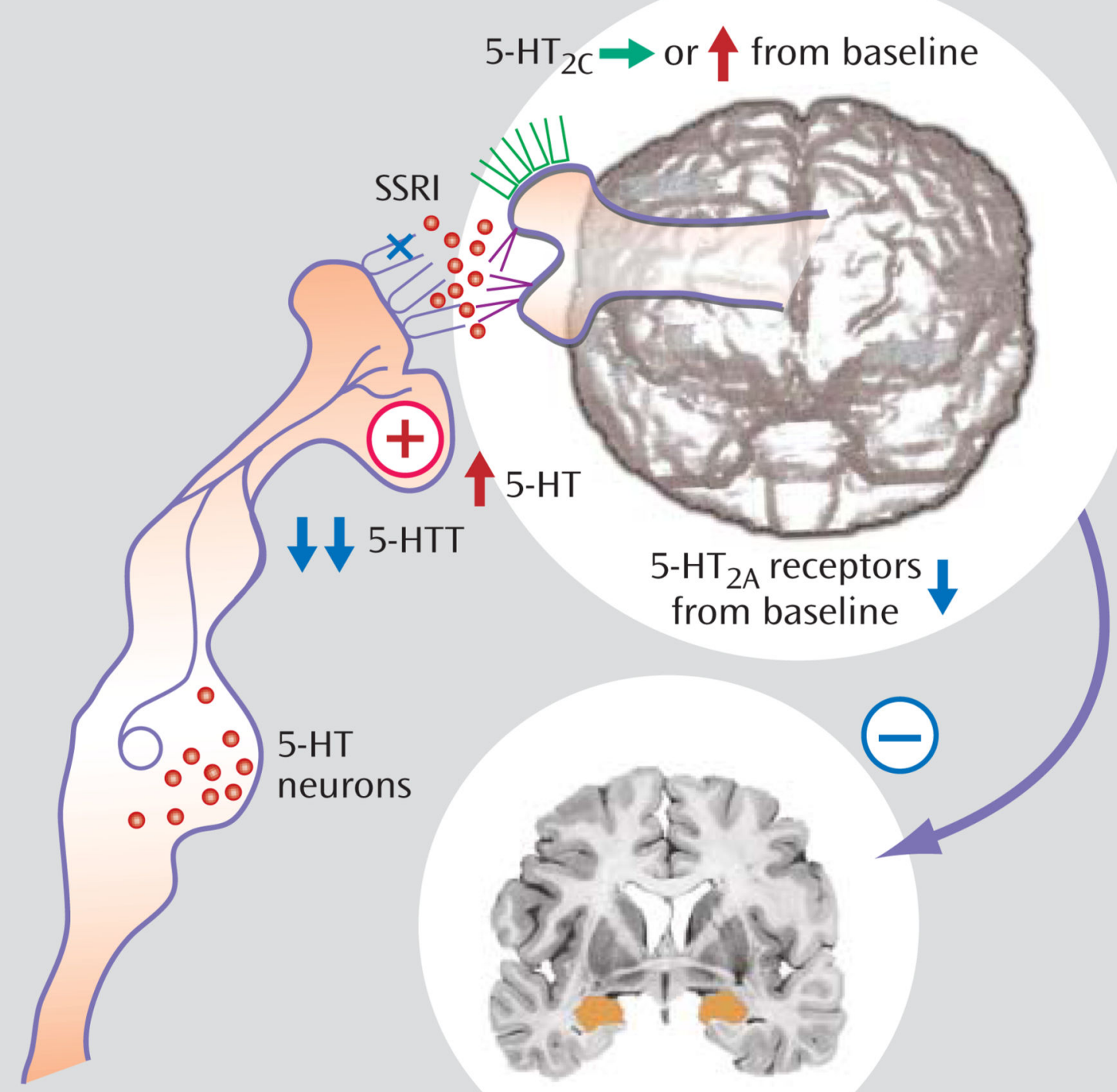

\section{Amygdala}

FIGURE 5.

Posttreatment Abnormalities in the Pathophysiology of Aggression ${ }^{\mathrm{a}}$

${ }^{a}$ Figure adapted/modified with permission from S.J. DeArmond et al., "Structure of the Human Brain: A Photographic Atlas, Third Edition" [Oxford University Press, New York, 1989]. Copyright (C) Oxford University Press. A modified version of this figure appeared in Davidson et al., Science 2000; 289:591. 


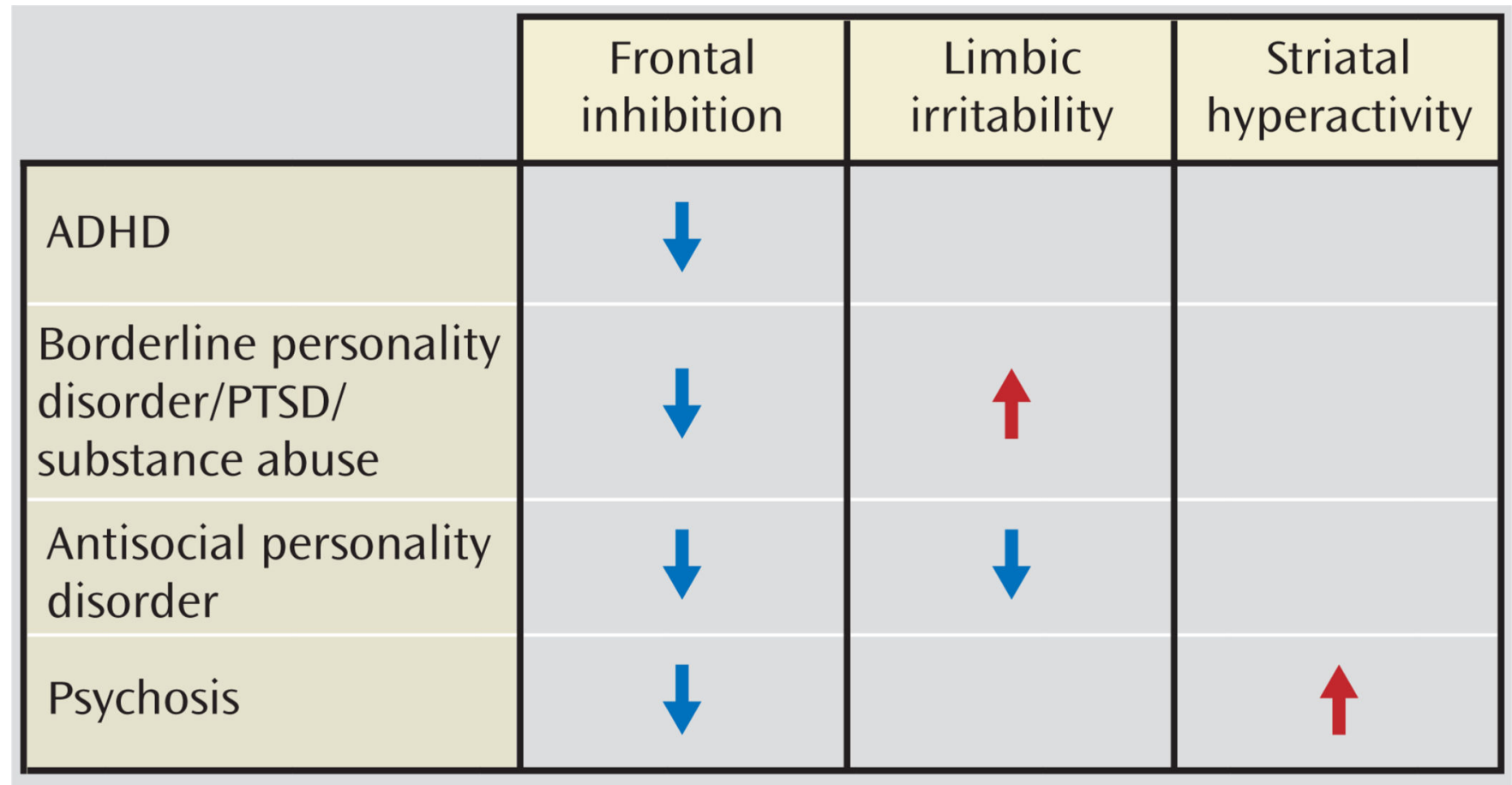

FIGURE 6.

Mechanisms of Aggression in Different Psychiatric Disorders 


\section{Neurobiological Applications: Pharmacotherapy}

\begin{tabular}{|l|l|c|}
\hline \multirow{2}{*}{$\begin{array}{c}\text { Pharmacologic } \\
\text { Class }\end{array}$} & \multicolumn{2}{|c|}{ Target } \\
\cline { 2 - 3 } Anticonvulsants & $\downarrow$ (limbic irritability) & \\
Serotonergic reuptake & & $\boldsymbol{\uparrow}$ (frontal inhibition) \\
Atypical neuroleptics & $\downarrow$ (subcortical dopa- & $\boldsymbol{\uparrow}$ (frontal inhibition) \\
Stimulants & & $\uparrow$ (frontal inhibition) \\
Opiate antagonists & $\downarrow$ (opiates) & \\
\hline
\end{tabular}

FIGURE 7.

Neurobiological Implications for Pharmacotherapy of Aggression 